\title{
STUDIES OF THE KIDNEY IN ACUTE INFECTION
}

\author{
I. Observations with the Urine Sediment Count (Addis) in \\ ACUTE RHEUMatic INFECTION ${ }^{1}$
}

By WILLIAM GOLDRING AND JOHN WYCKOFF

(From the Department of Medicine and the Third (New York University) Division, Belleowe Hospital, New York City)

(Received for publication January 18, 1930)

Most of the present knowledge concerning structural changes in the kidney is the result of postmortem studies. An indirect approach to the understanding of structural changes in the living human kidney has been made possible by the researches of Volhard and Fahr (1), resulting in their pathogenetic classification. They have shown that with a fair degree of accuracy it is possible to predicate the anatomic renal defect upon known functional derangements. Addis (2) furthered this conception when he developed his clinical classification of Bright's disease. He accomplished this entirely by means of a quantitative study of the formed elements in the urine sediment. He called this procedure, the Sediment Count. After allowing for the number of formed elements found in the normal urine sediment (3), he found in the glomerular (hemorrhagic) type, a quantitative excess of red blood cells; in the degenerative types, a quantitative excess of white and epithelial cells; and in the sclerotic type, no quantitative difference from the normal.

It follows reasonably from the studies of both Volhard and Fahr, and Addis, that while severe and widespread capillary inflammation (vasculitis, acute diffuse glomerular nephritis, hemorrhagic nephritis) is characterized by hematuria, edema, hypertension, azotemia, retinitis, etc., mild and localized capillary inflammation (focal glomerular nephritis) may be characterized only by hematuria. The importance of recognizing these mild types of glomerulitis becomes significant, when one realizes the many instances of subacute and chronic glomer-

1 The expenses of this study were defrayed by the Committee for Encouragement of Medical Research (from the Rheumatic Fever Fund.) 
ular nephritis in which a history of onset is either lacking or not clear. The further importance for the early recognition of kidney damage is that it is held by many workers that so-called nephrosis may result from early and microscopically unrecognizable capsule damage allowing the loss of protein into the glomerular filtrate with the later development of the classical train of signs and symptoms.

The sediment count, as proposed by Addis, seemed to be the method best adapted for making a study of the urinary sediment in acute infection. The infectious disease in which this study was made, was acute rheumatic infection.

\section{METHOD}

The sediment count, as described by Addis (2), was carried out in detail. During the febrile stage it was found to be unnecessary to restrict fluids on the day of the test, since such urines were of sufficient concentration and $\mathrm{pH}$ to preserve hyalin casts. The urine specimen was collected between 8 and 9 a.m. in a single voiding, 12 hours after the bladder had been emptied. This collection was under the direct supervision of a special nursing staff. ${ }^{2}$ A wide mouthed glass bottle was used, which had been washed previously with boiling water and rinsed with 1 per cent formalin solution. After thoroughly shaking, $10 \mathrm{cc}$. of the fresh specimen were transferred to a specially constructed and graduated Addis centrifuge tube ${ }^{3}$ and centrifuged at a moderate speed for 15 minutes. Nine cubic centimeters of the supernatant fluid were pipetted off and the sediment thoroughly mixed in the remaining $1 \mathrm{cc}$. When the sediment was small in amount, it was mixed in $0.5 \mathrm{cc}$. and this procedure allowed for in the calculation. A drop of this mixture was placed on a blood counting chamber and the red, white and epithelial cells and casts were counted as prescribed by Addis. Squamous epithelial cells were not counted, but round epithelial cells were included in the leucocyte count because of the difficulty in differentiating them. In this study, red blood cells regarded as significant were those which gave evidence of having been

2 The expense of this special nursing staff was met in part by the Crane fund and in part by the fund of the Committee for Encouragement of Medical Research (for the Study of Rheumatic Fever.)

${ }^{3}$ These tubes are obtained through Arthur H. Thomas and Company, Philadelphia. 
in the urine for some time by their laked appearance. It is felt that "rings" or "ghosts" are blood cells derived from the glomerulus $(4,6)$. Round uric and crystals and occasionally yeast cells are often very difficult to distinguish from red blood cells. Confidence in this differentiation comes only after careful study of many types of urine sediment.

Fresh appearing, refractile, hemoglobin-filled red blood cells were only occasionally found in the rheumatic patients and not included in the count.

Protein excretion was determined on the supernatant urine drawn off after centrifuging. The quantitative protein output was obtained by the centrifuge method developed by Shevky and Stafford (5) with a modification of the final calculation as suggested by Addis. ${ }^{4}$

The $\mathrm{pH}$ of the urine was determined colorimetrically with phenol red and methyl red.

In selecting patients for this study we excluded all those with any evidence of congestive heart failure, realizing that renal congestion would modify the urinary sediment.

\section{RESULTS}

Table 1 indicates the sediment findings in 21 different normal individuals. With the exception of the red cell average, our results are closely comparable to those obtained by Addis in a much larger series (3). With the two counts on patient 7 excepted, our highest normal red cell excretion was two hundred thousand in 12 hours. In only two instances did the white and epithelial cell excretion exceed one million for 12 hours. Casts were found in only three of twenty-two counts and were all of the hyalin variety.

Table 2 indicates the results of 86 sediment counts on 16 patients with acute rheumatic infection. The average figures represent a distinct increase in the excretion of formed elements, over the normal. The period of observation ranged from 8 to 98 days, and counts were repeated on each patient at weekly intervals. After discharge from the hospital, follow-up counts were made on readmission from the outpatient clinic. Increased excretion of formed elements in the urine

4 Personal communication. 
continued well into convalescence in the patients studied, and at the time of discharge from the hospital only two of the sixteen had returned to normal. Of the remaining fourteen patients, three were uncoöperative and eleven were approaching the normal range after four to ten weeks of convalescence. In no instance did hypertension,

TABLE 1

Urine sediment count in normal persons

\begin{tabular}{|c|c|c|c|c|c|c|c|}
\hline Number & pH & $\begin{array}{l}\text { Specific } \\
\text { gravity }\end{array}$ & $\begin{array}{c}\text { Urine } \\
\text { volume }\end{array}$ & Protein & Red cells & $\begin{array}{l}\text { White and } \\
\text { epithelial } \\
\text { cells }\end{array}$ & Casts $\nmid$ \\
\hline & & & $\begin{array}{c}c c . \text { per } \\
12 \text { hours }\end{array}$ & $\begin{array}{l}\text { mgm. per } \\
12 \text { hours }\end{array}$ & $\begin{array}{l}\text { millions } \\
\text { per } 12 \text { hours }\end{array}$ & $\begin{array}{c}\text { millions } \\
\text { per } 12 \text { hours }\end{array}$ & $\begin{array}{l}\text { thousands } \\
\text { per } 12 \text { hours }\end{array}$ \\
\hline 1 & 5 & 1.028 & 80 & 5.75 & 0.022 & 0.52 & 0 \\
\hline 2 & 5 & 1.030 & 369 & 5.3 & 0 & 0.22 & 9.2 \\
\hline 3 & 6.5 & 1.024 & 387 & 13.9 & 0.072 & 0.097 & 0 \\
\hline 4 & 5 & 1.034 & 137 & 2.9 & 0.076 & 0.34 & 0 \\
\hline 5 & 5 & 1.038 & 274 & 60.2 & 0.034 & 0.18 & 0 \\
\hline 6 & 5 & 1.036 & 414 & 17.88 & 0.145 & 0.028 & 0 \\
\hline \multirow[t]{2}{*}{7} & 5.5 & 1.038 & 355 & 15.33 & 0.931 & 0.047 & 3.9 \\
\hline & 5 & 1.043 & 280 & 10.0 & 1.53 & 0.024 & 0 \\
\hline 8 & 5 & 1.040 & 259 & 18.0 & 0 & 0.064 & 0 \\
\hline 9 & 5.5 & 1.042 & 210 & 9.0 & 0.157 & 0.131 & 0 \\
\hline 10 & 6.5 & 1.026 & 385 & 22.1 & 0.159 & 0.192 & 0 \\
\hline 11 & 5 & 1.036 & 147 & & 0.009 & 0.082 & 0 \\
\hline 12 & 5 & 1.040 & 158 & 5.6 & 0.013 & 0.115 & 0 \\
\hline 13 & 5 & 1.031 & 473 & 10.2 & 0 & 0.118 & 0 \\
\hline 14 & 5.5 & 1.023 & 355 & 12.78 & 0 & 0.117 & 0 \\
\hline 15 & 5 & 1.044 & 208 & 8.9 & 0 & 0.062 & 0 \\
\hline 16 & 5 & 1.032 & 287 & 15.4 & 0.071 & 0.262 & 0 \\
\hline 17 & 5 & 1.020 & 616 & 22.1 & 0 & 0.077 & 0 \\
\hline 18 & 5.5 & 1.026 & 343 & 17.2 & 0.028 & 0.056 & 0 \\
\hline 19 & 5 & 1.034 & 120 & 7.76 & 0.127 & 3.40 & 0.5 \\
\hline 20 & 5.5 & 1.027 & 205 & 10.2 & 0.205 & & 0 \\
\hline 21 & 5.5 & 1.032 & 335 & 21.7 & 0.027 & 1.36 & \\
\hline Average. & 5.27 & 1.032 & 289 & 14.68 & 0.1639 & 0.3568 & 0.6475 \\
\hline
\end{tabular}

* Centrifuge method (see reference 5).

$\dagger$ All casts in this group are of the hyalin variety.

retinitis, or generalized edema occur. The blood chemical findings were normal throughout.

It is apparent from table 3 that the formed elements are excreted in greater numbers during the more acute stages of the disease, i.e., when the temperature is higher. A comparison of a qualitative and 


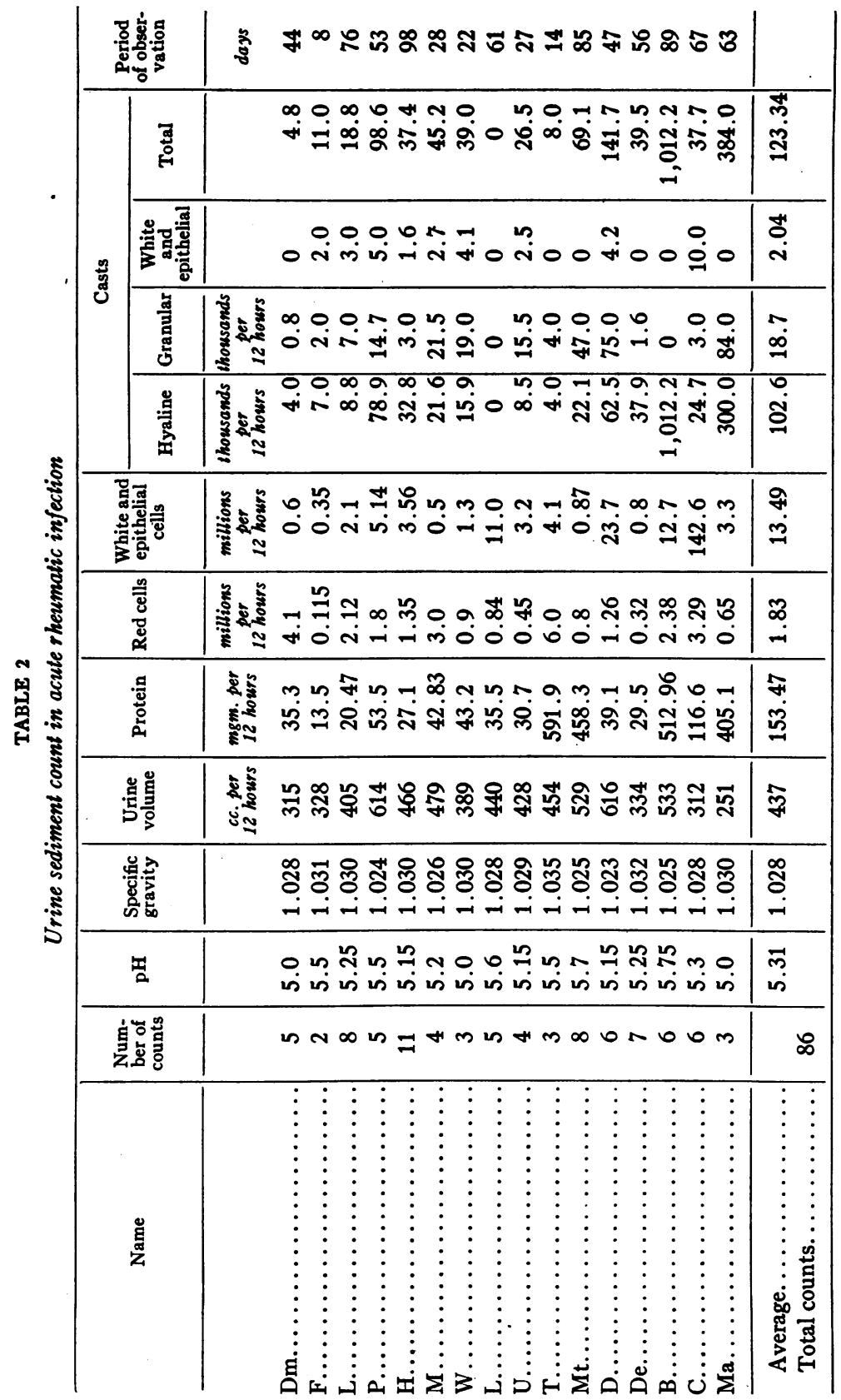


the quantitative centrifuge method for the estimation of protein excretion, performed by two separate observers on the same urine specimens, is shown in table 4 . The results are comparable and entirely satisfactory for this study.

\section{COMMENT}

Such a urine picture as described in this study, in the absence of systemic effects as hypertension and edema, is consistent with a diagnosis of focal glomerulonephritis according to the classification of

TABLE 3

Relation of temperature to excretion of formed elements in the urine

\begin{tabular}{|c|c|c|c|c|}
\hline Temperature & Red cells & $\begin{array}{l}\text { White and } \\
\text { epithelial cells }\end{array}$ & Casts & $\begin{array}{l}\text { Total number of } \\
\text { counts }\end{array}$ \\
\hline${ }^{\circ} \mathrm{F}$. & $\begin{array}{c}\text { millions per } 12 \\
\text { kours }\end{array}$ & $\begin{array}{c}\text { millions per } 12 \\
\text { hours }\end{array}$ & $\begin{array}{c}\text { thousands per } 12 \\
\text { hours }\end{array}$ & \\
\hline Normal & 0.1639 & 0.3568 & 0.6475 & 22 \\
\hline 99-101 & 0.8571 & 3.360 & 5.323 & 70 \\
\hline $101-105$ & 3.8100 & 56.340 & 495.300 & 16 \\
\hline
\end{tabular}

TABLE 4

Comparison of qualitative and quantitative methods for estimation of protein excretion

\begin{tabular}{c|c}
\hline Heat and acetic acid & Centrifuge method $\dagger$ \\
\hline & mgm. per 12 hours \\
0 & 19.76 \\
Trace & 65.64 \\
1 and 2 & 198.50 \\
3 and 4 & 2085.00
\end{tabular}

* $0=$ none; trace $=$ very faint cloud; 1 and $2=$ moderate to heavy cloud; 3 and $4=$ moderate to heavy precipitate.

† Shevky and Stafford (see reference 5).

Volhard and Fahr. Likewise, the excessive excretion of white blood cells, round epithelial cells, and casts, during the acute stage and for some weeks of the convalescent period, would indicate an associated tubular degenerative lesion. In our series, all were of a mild type, and apparently subsided with the underlying acute infection. The severe type of acute nephritis (diffuse vasculitis) which occasionally complicates scarlatina and streptococcus infections did not occur in this series. Since there seemed no reason to believe that the urine 
sediment findings described were peculiar to rheumatic infection alone, we have undertaken to study the urine sediments quantitatively in various other infections. This study is now in progress.

\section{SUMMARY}

By means of the sediment count it has been shown that an appreciable number of formed elements are excreted in the normal urine. This number has been determined.

In a series of 16 patients with acute rheumatic infection, excretion of protein and formed elements occurred in excess of the normal. The red blood cells in this group differed from those in the normal group, in their laked and crenated appearance.

The abnormal excretion rate of formed elements persisted for four to ten weeks after subsidence of the acute attack of rheumatic infection.

There was a direct relationship between the height of the temperature and the excretion of protein and formed elements.

\section{BIBLIOGRAPHY}

1. Volhard, F., and Fahr, T., Die Brightsche Nierenkrankheit. Berlin, 1914

2. Addis, T., J. Am. Med. Assoc., 1925, lxxxv, 163. A Clinical Classification of Bright's Disease.

3. Addis, T., J. Clin. Invest., 1926, ii, 409. The Number of Formed Elements in the Urinary Sediment of Normal Individuals.

4. Todd, J. C., Clinical Diagnosis by Laboratory Methods. W. B. Saunders Co., 1923, 5th ed. p. 213.

5. Shevky, M. C., and Stafford, D. D., Arch. Int. Med., 1923, xxxii, 222. A Clinical Method for the Estimation of Protein in Urine and Other Body Fluids.

6. Webster, R. W., Diagnostic Methods. P. Blakiston's Son \& Co., 1916, 5th ed., p. 355 . 